\title{
Outro ventre
}

Do ventre eu não vim

Nesse mundo de ares

Onde o sol nasce torto

Onde tudo desfaz

Do ventre eu não vim

Nesse mundo de cores

Onde a terra é quadrada

Onde a margem é o cais

Do ventre eu não vim

Nesse mundo de flores

Onde a paz é a guerra

Onde o tempo é o mais

Do ventre eu não vim

Nesse mundo de almas

Onde a dor é o canto

Onde tudo se esvai

\footnotetext{
* Estudante em Letras Língua Portuguesa na Universidade Federal de Campina Grande (UFCG). E-mail: thaysebsilva@gmail.com.
} 